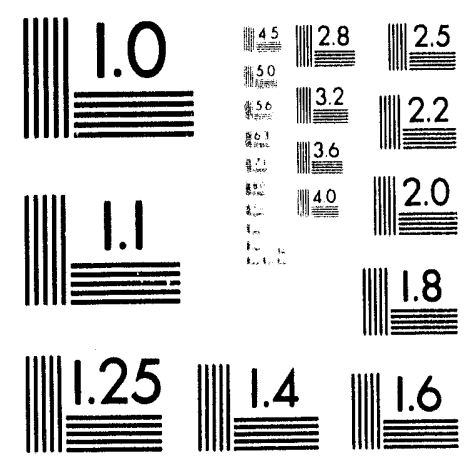



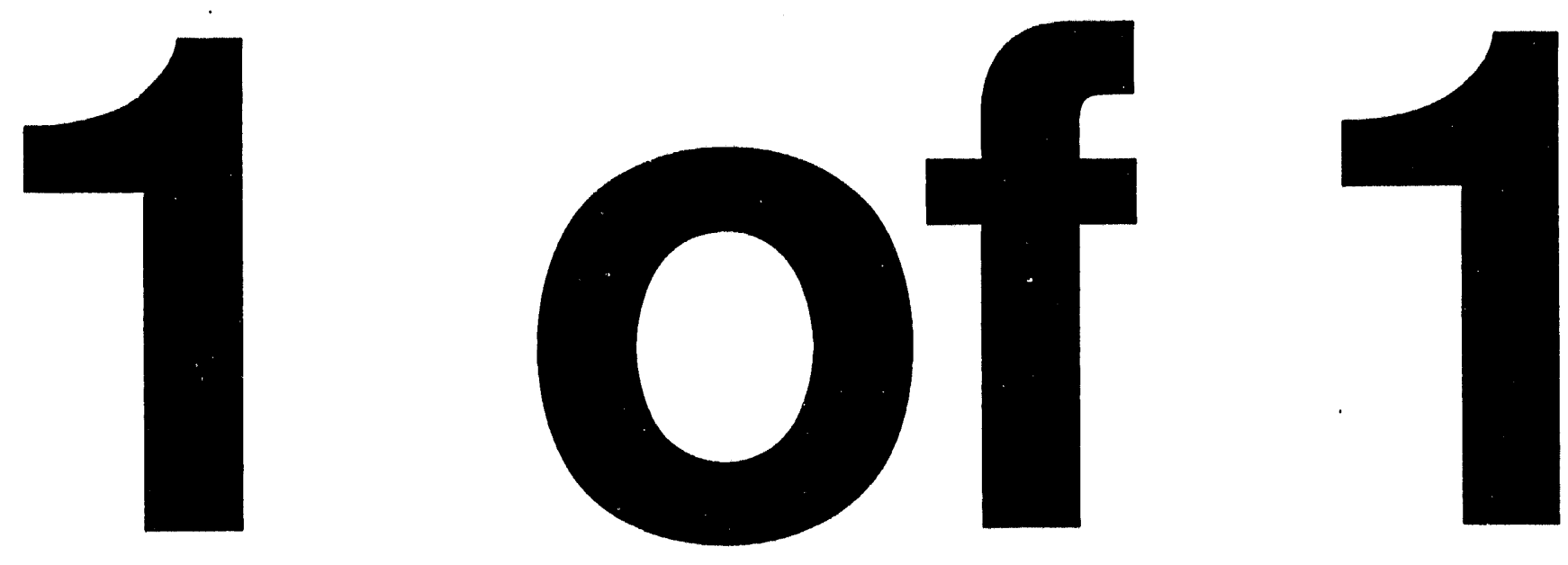


\title{
ZIRCONS AND FLUIDS: AN EXPERIMENTAL INVESTIGATION WITH APPLICATIONS FOR RADIOACTIVE WASTE DISPOSAL
}

PROGRESS REPORT ON

- STABILITY OF ZIRCONS

)

\author{
A.K. SINHA \\ Virginia Polytechnic Institute 'and State University \\ Department of Geological Sciences \\ Blacksburg, Virginia 24061
}

JANUARY 1992 - DECEMBER 1992

) Prepared for the U.S. Department of Energy under contract No. DE-FG05-88ER13951

\section{DISCLAIMER}

This report was prepared as an account of work sponsored by an agency of the United States Government. Neither the United States (iovernment nor any agency thereof, nor any of their employees, makes any warranty, express or implied, or assumes any legal liability or responsibility for the accuracy, completeness, or usefulness of any information, apparatus, product, or process disclosed, or represents that its use would not infringe privately owned rights. Reference herein to any specific commercial product, process, or service by trade name, trademark, manufacturer, or otherwise does not necessarily constitute or imply its endorsement, recom. mendation, or favoring by the United States (jovernment or any agency thereof. The views and opinions of authors expressed herein do not necessarily state or reflect those of the United States Government or any agency thereof. 


\begin{abstract}
The long-term stability of nuclear waste forms or barriers is related to changes in physical properties of the material induced through radiation damage and subsequent changes in solubility. Investigations conducted by us on natural zircons $\left(\mathrm{ZrSiO}_{4}\right)$ supports a positive correlation between level of alpha damage and fluid composition to enhanced levels of corrosion. In this report we present preliminary data on the nature and rate of the solution process involving $<600,000$ year-old zircons being affected by natural fluids in geyser fields of Yellowstone National Park. We also summarize our continuing activity by including in this report articles that have been published or are in press in refereed journals.
\end{abstract}

\title{
Introduction
}

Polyphase crystalline waste forms, such as the various proposed Synroc assemblages (e.g., Ringwood et al., 1979; Ringwood, 1985) are thought to be superior to noncrystalline waste forms hecause the latter are highly susceptible to hydrothermal alteration by aqueous brines at elevated temperatures, resulting in the release and transport of potentially dangerous waste constituents (McCarthy et al., 1978). However, questions have been raised as to the ability of crystalline waste forms to resist chemical alteration as radiation damage accumulates. Studies by Ewing and Headley (1983) and Lumpkin and Ewing (1985) have shown that zirconolite and pyrochlore, both natural analogues to the proposed Synroc constituents, may undergo complete amorphitization and subsequently suffer hydration and loss of A-site cations $(\mathrm{Ca}, \mathrm{Na})$ as the result of long-term weathering processes. Other major constituents of Synroc (e.g., Ba-Ti hollandite) are not found in nature; thus, their resistance to natural leaching processes cannot be ascertained. Furthermore, experimental evidence (Nesbitt et al., 1980) has indicated that Syrroc constituent minerals, such as perovskite, may be thermodynamically unstable in a silicarich environment. 
Naturally-occurring refractory phases, such as monazite, sphene and zircon, are known by geoscientists to be stable in a wide range of geologic environments (both silica saturated and silica undersaturated) and have been proposed as constituents of crystalline. ceramic and composite waste forms (e.g., Harker and Flintoff, 1984; Ewing and Haaker, 1980; Hayward et al., 1983, Sinha et al., 1989, 1990, 1991). The long-term stability of natural monazite, sphene and zircon samples has been discussed in terms of their resistance to $\mathrm{U}-\mathrm{Th}-\mathrm{Pb}$ isotopic loss throughout geologic time, their relative insolubility, refractory nature, and in the case of monazite, an apparent resistance to radiation damage.

Of all the aforementioned minerals, the most thoroughly investigated mineral with regards to isotopic systematics, crystal chemistry and radiation damage is zircon. Furthermore, a vast amount of data on the behavior of the zircon $\mathrm{U}-\mathrm{Pb}$ isotopic system in a wide variety of rock types has been obtained. The chemical and isotopic response of zircons to fluids is poorly understood, but there is a general consensus that radiationdamaged crystals are more likely to be isotopically discordant and act as an open system to cation transport (Krogh, 1982; Wayne and Sinha, 1988). Although it has been proposed that the retentivity of $\mathrm{Pb}$ in zircons is indicative of the stability of the mineral at below $-300^{\circ} \mathrm{C}$ (Gentry et al., 1982), strong arguments against such a model have been presented by Ludwig et al. (1984). These disagreements are clear indications of the lack of a data base in which relationships among crystal chemistry, age, and radiation damage may be clarified.

Our current research is aimed at providing a new physical, chemical and isotopic data base for zircons $\left(\mathrm{ZrSiO}_{4}\right)$, using both natural and synthetic crystals. Because of the clear relationship between enhanced solubility (leachability) and $\alpha$-damage, we are now in a position to attempt to quantify this process through: (1) long-term calibrated studies on the reactivity of $\mathrm{ZrSiO}_{4}$ in fluids at repository conditions (1000 bars and lower pressures and up to $400^{\circ} \mathrm{C}$ ) and (2) studies of the mechanics of fractures induced due to both radiation and temperature-unhanced stresses. Both objectives are clearly and uniquely 
related to the DOE mission of careful documentation and characterization of possible waste form containment materials. In this progress report we present new analytical data on the reactivity of zircon in a hydrothermal environment.

Using the unpolished surfaces we have measured elemental abundances for zircons within, as well as outside geyser fields in Yellowstone National Park. However, no significant differences can be detected, and if either selective depletion or gain of $\mathrm{ZrO}_{2}$ and $\mathrm{SiO}_{2}$ and other elements have occurred, microprobe techniques cannot measure these differences.

\section{Response of Zircons to Fluids in Natural}

\section{Hydrothermal Systems}

As part of our ongoing assessment of the stability of zircon in various hydrothermal environments, this preliminary report provides information on zircons in geyser fields. The Yellowstone National Park area is underlain by both Archean age (>2700 m.y.) and very young ( $<600,000$ years) volcanic tuffs and flows of felsic composition. The area is also dominated by hydrothermal activity - a number of rock types act as hosts for the location of hot springs. As part of our research, we are in the process of studying zircons with variable uranium contents within rocks of various ages that have been extensively attacked by hot fluids. This environment provides an unique opportunity to evaluate the response of zircons to a hot fluid over a time period of several tens of thousands of years and presents an unique opportunity to test the ability of zircon to retain uranium and lead over time intervals envisioned for repository sites.

Preliminary sampling of the young felsic tuffs within a hot spring area (Beryl Springs) and outside the hydrothermal zone has been completed. Zircons extracted from the altered and fresh tuffs are shown in Figure 1. There is a hint of corrosion of the hydrothermally altered zircons, and in this report we provide preliminary microprobe data on (a) chemical changes (alteration) induced by the hot fluids and (b) evidence for 

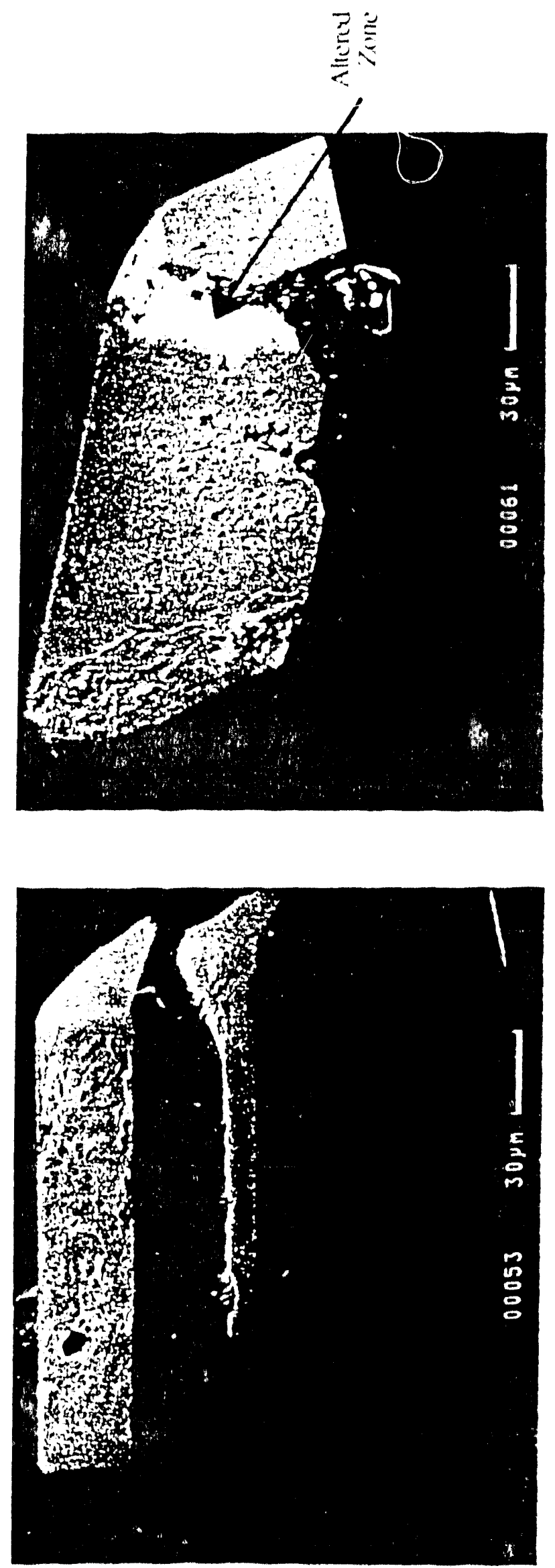

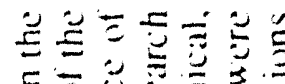

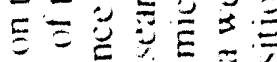

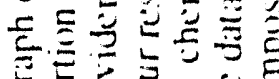

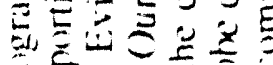

$=\subseteq \quad \equiv$

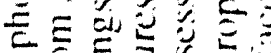

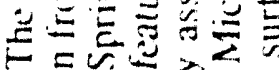

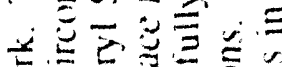

昰昰率

$\bar{\Xi} \bar{\nabla}$

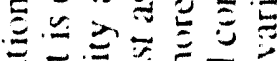

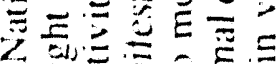

ป

E气

Е

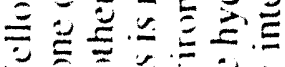

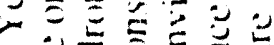

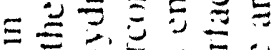

三E三主

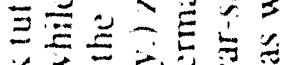

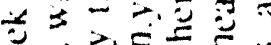

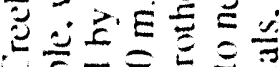

高可哥

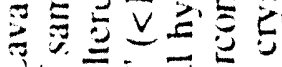

三

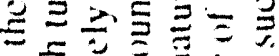

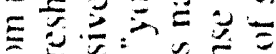

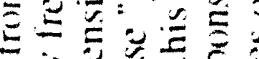

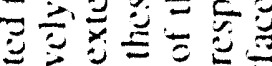

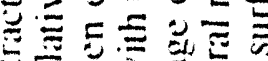

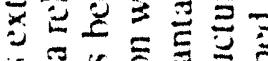

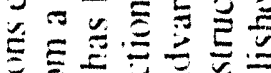

可氙司

可导焉

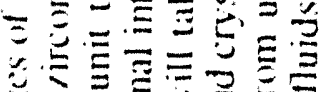

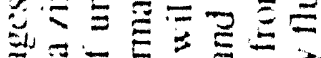

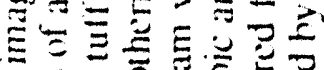

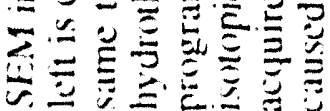


development of surface corrosion features. If we can demonstrate that zircons of varying ages (older ones still to be collected from Archean rocks exposed to hydrothermal activity, e.g., near Trudeau, Montana and Norris, Montana) have acted as relatively stable minerals over tens of thousands of years, then $\mathrm{ZrSiO}_{4}$ must be considered as a form for $\mathrm{RAD}$ waste repository sites.

The analytical data for zircons recovered from both the fresh and hydrothermally altered tuffs is given in Table 1. Although we have a microprobe analytical program specifically designed for zircon analyses, the apparent surface chemistries are not measurably different. We have chosen to utilize unpolished surfaces for compositional studies to permit us to gather information on incongruent versus congruent dissolution processes (e.g., Sinha et al., 1991).

The average element chemistries of the two types of zircons show no significant differences (Table 1), but there is some evidence that $\mathrm{Th}, \mathrm{Yh}$ and $\mathrm{U}$ are higher on the surfaces of the altered zircons. Because of the difficulties in measurements of trace concentrations using microprobe methods, we are not able to more formally highlight significant differences.

We propose to pursue surface analytical schemes using ICP-MS techniques with laser systems, if timely access to such instruments can be acquired at other institutions. 


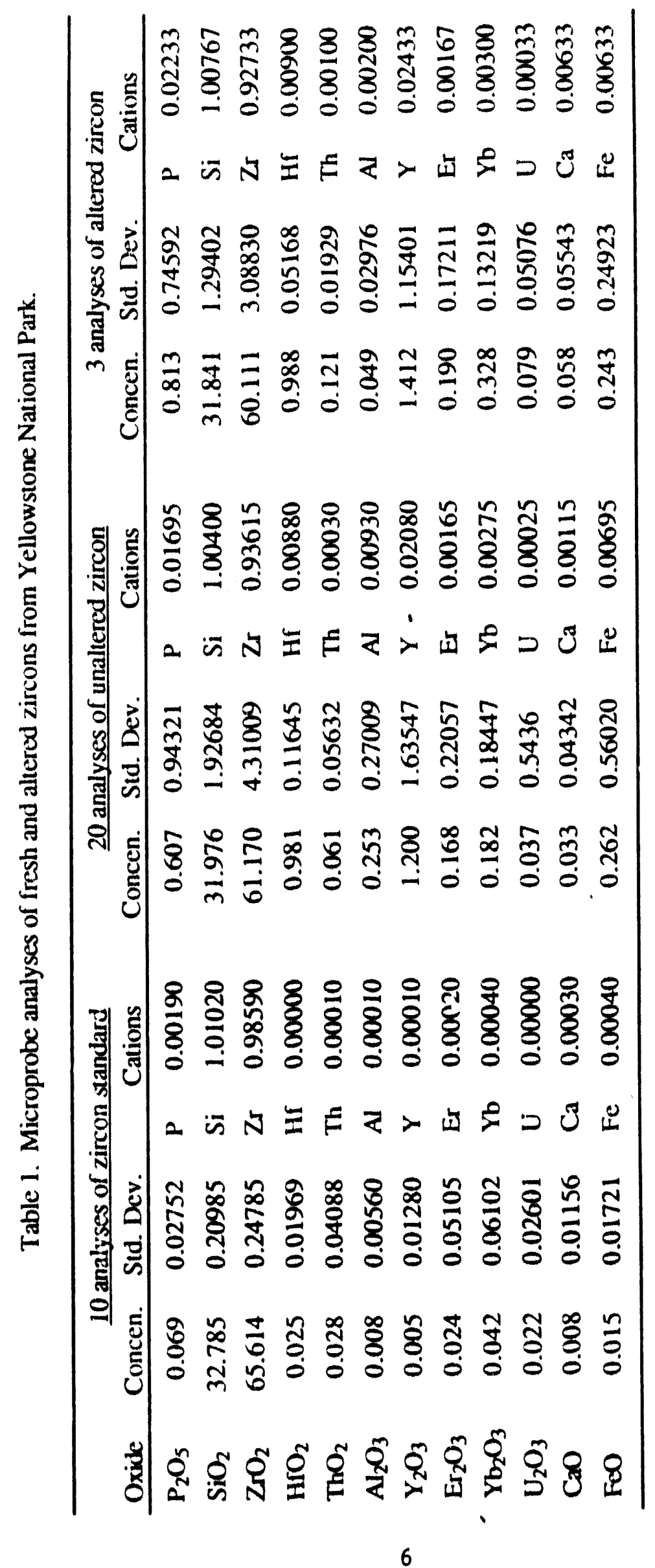




\section{References}

Ewing. R.C. and R.F. Haaker (1980) The metamict state: Implications for radiation damage in crystalline waste forms. Nucl. Chem. Waste Management, 1, 51-57.

Ewing, R.C. and T.J. Headley (1983) Alpha-recoil damage in natural zirconolite $\left(\mathrm{CaZrTi}_{2} \mathrm{O}_{7}\right)$. J. Nucl. Mat., 199, 102-109.

Gentry, R.V., T.J. Sworski, H.S. Mckown. D.H. Smith, R.E. Ehy and W.HI. Christie (1982) Differential lead retention in zircons: Implications for nuclear waste containment. Science, 216, 2\%6-298.

Harker, A.B. and J.F. Flintoff (1984) Polyphase ceranic and glass-ceramic forms for immobilizing ICPP high-level nuclear waste. In C.L. McVay, ed., Scientific Basis for Nuclear Waste management-VII, p. 513.520 .

Hayward, P.J., F.E. Doem, E.V. Cecchelto and S.L. Mitchell (1983) Leaching studies of natural and synthetic titanite, a potential host for wastes from the reprocessing of Canadian nuclear fuel. Can. Mineral., 21, 611-623.

Krogh, T.E. (1982) Improved accuracy of U.Ph zircon ages by the creation of more concordant systeins using an air abrasion technique. Gexchim. Cosmochim. Acta, 46, 637-649.

Lumpkin, G.R. and R.C. Ewing (198.5) Natural pyrochlores: Analogues for actinide host phases in radionctive waste forns. In C.M. Jantzen et al., eds., Materials Research Society Symposium, Proxecedings v. 44, 647-654. Materials Research Scxiety, Pillsburgh, Pennsylvania.

Ludwig, R.E., R.E. Zarunan and S.S. Goldich (1984) Lead retention in zircons. Science, 223, 835.

McCarthy, G.J., S. Komarneni, B.E. Scheetz and W.B. White (1978) Hydrothermal reactivity of simulated nuclear waste forms and water-catalysed waste forms and water-catalysed waste-ruck interactons. In G.J. McCarthy, ed., Scientific Basis for Nuclear Waste Management, p. 329.340.

Neshill, H.W., G.M. Bancrift, W.S. Fyfe, S. Karkhanis, P. Melling and A. Nishimjima (1980) On the thermodymanic and kinetic stability of perovskite in natural waters. In Workshop on Alternate Nuclear Waste Forms and Interactions in Geologic Media, Gatlinburg. Tennessee.

Ringwond, A.E. (1985) Disposal of high-level nuclear wastes: A geological perspective. Mineral. Mag., $49,159.176$.

Ringwood, A.E., S.E. Kesson, N.G. Ware, W. Hibberson and A. Major (1979) limmobilization of highlevel nuclear wastes in Synroc. Nature, 178-219.

Sinha, A.K., D.A. Hewill, P.H. Ribbe and D. Wayne (1989) Zircons and fluids. Progress Report VPI \& SU 13951.1 for Dept. of Energy Contract No. DE.FG05-88ER13951.

Sinha, A.K.. D.A. Hewill, P.H. Ribbe and D. Wayne (1990) Zircons and fluids. Progress Report VPI \& SU 13951.2 for Dept. of Energy Contract No. DE-FG05-88ER13951.

Sinha, A.K.. J. Student and R. Essex (1991) Zircons and nuids. Progress Report VPI \& SU 13951-4 for Dept, of Energy Contract No. DE.FG05.88ER13951.

Wayne. D.M. and A.K. Sinha (1988) Physical and chemical response of zircons to deformation. Contrib. Mineral. Petrol., 98, 109.121.

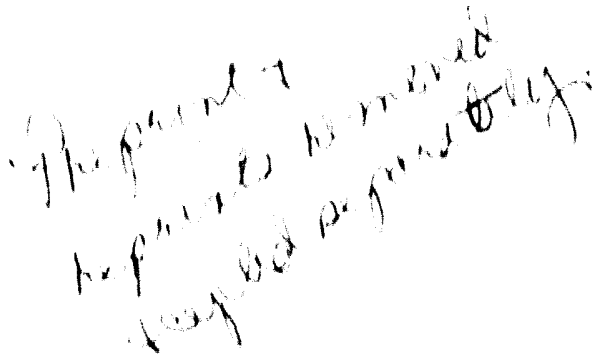



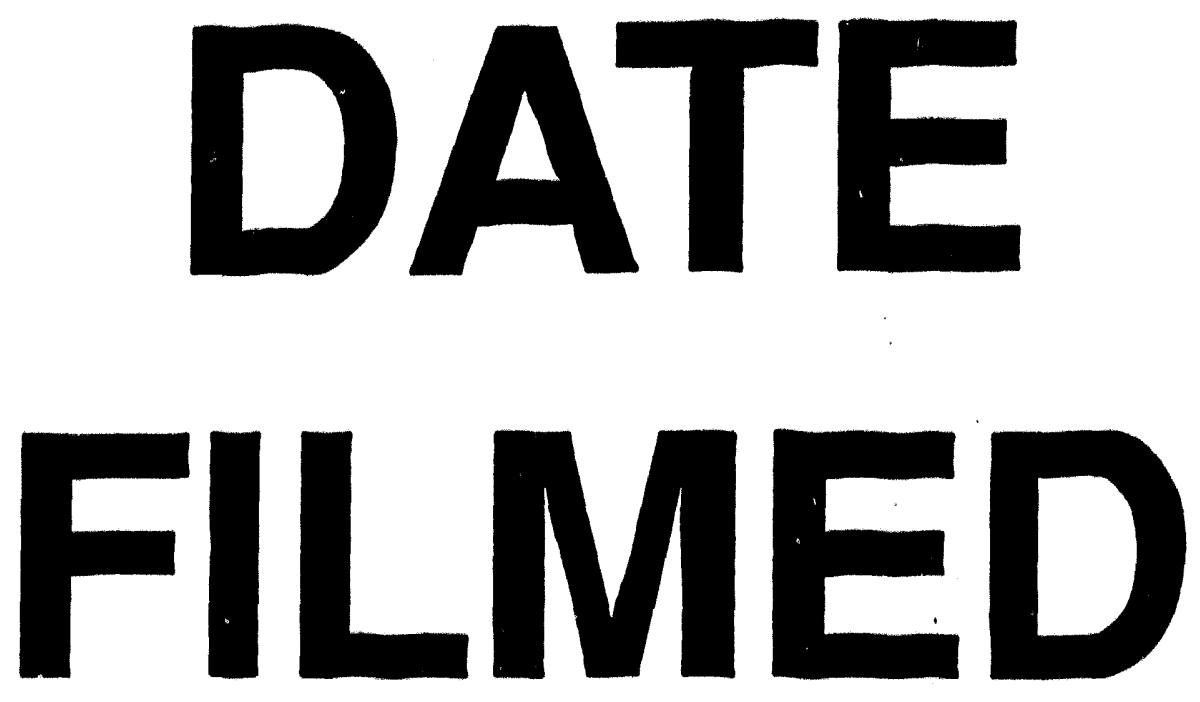

$11 / 19 / 93$
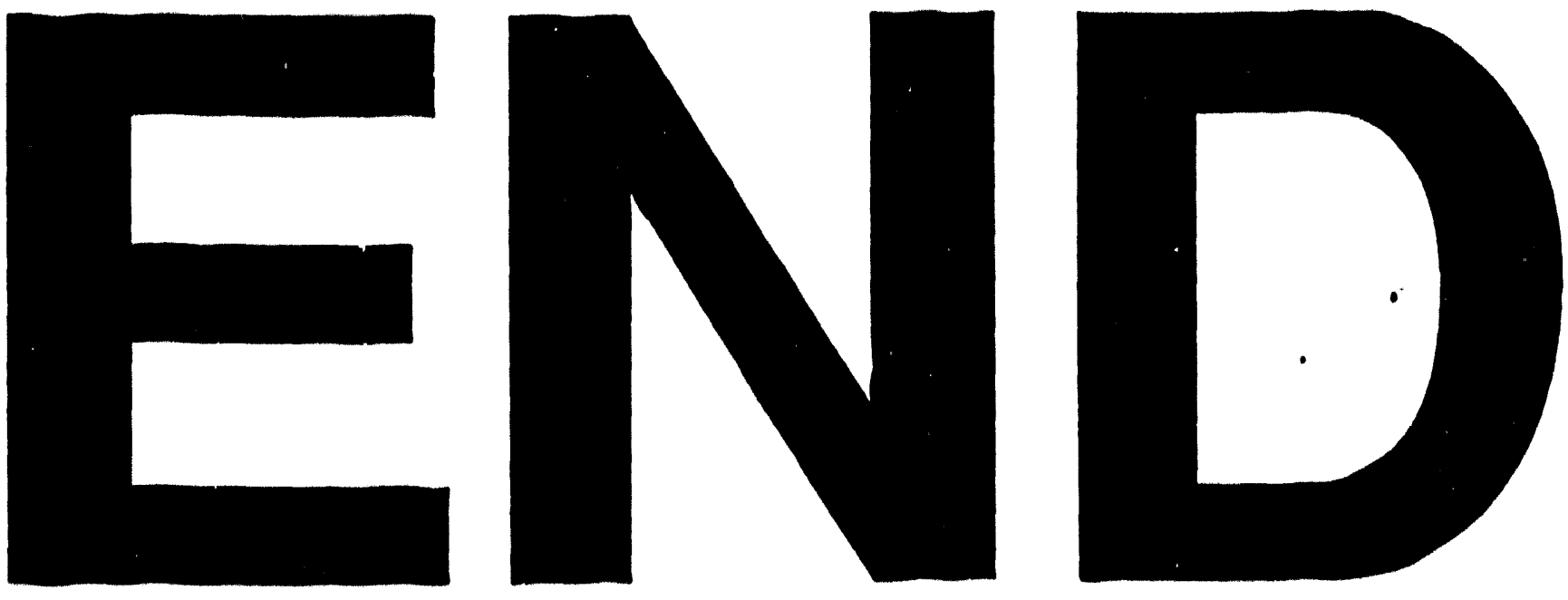


$$
-\ldots
$$

